\title{
Modified revascularization technique in permanent molars. A case series
}

\author{
Técnica de revascularização modificada em molares permanentes. Uma série de casos \\ Técnica de revascularización modificada en molares permanentes. Una serie de casos
}

Received: 03/31/2021 | Reviewed: 04/10/2021 | Accept: 04/19/2021 | Published: 05/04/2021

\author{
Lilian Vieira Oliveira \\ ORCID: https://orcid.org/0000-0002-1805-8302 \\ Federal University of Uberlândia, Brazil \\ E-mail: lvoliveira@live.com \\ Anahi de Paula Melo \\ ORCID: https://orcid.org/0000-0002-2677-5475 \\ Federal University of Uberlândia, Brazil \\ E-mail: anahi.melo@unesp.br \\ Priscilla Barbosa Ferreira Soares \\ ORCID: https://orcid.org/0000-0002-4492-8957 \\ Federal University of Uberlândia, Brazil \\ E-mail: pbfsoares@yahoo.com.br \\ Juliane Maria Guerreiro-Tanomaru \\ ORCID: https://orcid.org/0000-0003-0446-2037 \\ Dental School of Araraquara, Brazil \\ E-mail: jutanomaru@uol.com.br \\ Carlos José Soares \\ ORCID: https://orcid.org/0000-0002-8830-605X \\ Federal University of Uberlândia, Brazil \\ E-mail: carlosjsoares@ufu.br \\ Camilla Christian Gomes Moura \\ ORCID: https://orcid.org/0000-0002-5653-8403 \\ Federal University of Uberlândia, Brazil \\ E-mail: camillahistologia@yahoo.com.br
}

\begin{abstract}
There are few reports of regenerative endodontic procedures in molars, and most using manual root canal preparation. This case series describes a modified revascularization technique used in permanent molars (five patients between 9 and 16 years old). Patients were referred by an emergency service and a diagnostic hypothesis was made based on the patient's reports. At the first appointment, coronal preparation was performed using Hedstroem files and Gates Glidden drills, followed by complete root canal preparation with rotary NiTi files. Calcium hydroxide $\left(\mathrm{Ca}(\mathrm{OH})_{2}\right)$ paste was used as intracanal medication. At the second appointment, intracanal medication was removed, followed by final irrigation with EDTA under ultrasonic agitation, and the clot was promoted. The entrances of the canals were sealed using a mineral trioxide aggregate sealer (MTA) and provisionally restored with a light-cured glass ionomer. All teeth were finally restored using direct composite resin restoration and were followed for up to 18 months, checking pain, edema, and fistula during clinical evaluation. Radiographic examinations were performed to assess apical repair until 15 months, where root apex closure and canal reduction were observed. After 6 months, evidence of healing was observed in all cases. It was possible to confirm that endodontic regeneration after mechanized root canal preparation, use of a MTA sealer, and direct composite resin restoration in molars is a promising option for maintaining permanent molars in adolescents.
\end{abstract}

Keywords: Adolescent; Regeneration; Molar tooth; Dental pulp.

\section{Resumo}

Existem poucos relatos de procedimentos endodônticos regenerativos em molares, e a maioria usando preparo de canal radicular manual. Esta série de casos descreve uma técnica de revascularização modificada usada em molares permanentes (cinco pacientes entre 9 e 16 anos). Os pacientes foram encaminhados por um serviço de emergência e foi feita a hipótese diagnóstica com base no relato do paciente. Na primeira consulta, o preparo coronal foi realizado com limas Hedstroem e brocas Gates Glidden, seguido de preparo completo do canal radicular com limas rotativas de NiTi. A pasta de hidróxido de cálcio $\left(\mathrm{Ca}(\mathrm{OH})_{2}\right)$ foi usada como medicação intracanal. Na segunda consulta, a medicação intracanal foi retirada, seguida da irrigação final com EDTA sob agitação ultrassônica e o coágulo foi promovido. As entradas dos canais foram seladas com selante de agregado trióxido mineral (MTA) e restauradas provisoriamente com ionômero de vidro fotopolimerizável. Todos os dentes foram finalmente restaurados com restauração direta de resina composta e foram acompanhados por até 18 meses, verificando dor, edema e fístula durante a avaliação clínica. Exames radiográficos foram realizados para avaliar o reparo apical até 15 meses, onde foi observado fechamento do ápice 
radicular e redução do canal. Após 6 meses, a evidência de cura foi observada em todos os casos. Foi possível confirmar que a regeneração endodôntica após o preparo mecanizado do canal radicular, o uso de um cimento MTA e a restauração direta de resina composta em molares é uma opção promissora para a manutenção de molares permanentes em adolescentes.

Palavras-chave: Adolescente; Regeneração; Dente molar; Polpa dentária.

\section{Resumen}

Hay pocos informes de procedimientos de endodoncia regenerativa en molares y la mayoría utiliza la preparación manual del conducto radicular. Esta serie de casos describe una técnica de revascularización modificada utilizada en molares permanentes (cinco pacientes entre 9 y 16 años). Los pacientes fueron remitidos por un servicio de urgencias y se formuló una hipótesis diagnóstica a partir de los informes de los pacientes. En la primera cita, la preparación coronal se realizó utilizando limas Hedstroem y fresas Gates Glidden, seguida de una preparación completa del conducto radicular con limas rotatorias NiTi. Se utilizó pasta de hidróxido de calcio $\left(\mathrm{Ca}(\mathrm{OH})_{2}\right)$ como medicación intracanal. En la segunda cita se retiró la medicación intracanal, seguida de la irrigación final con EDTA bajo agitación ultrasónica y se promovió el coágulo. Las entradas de los canales se sellaron con un sellador de agregado de trióxido mineral (MTA) y se restauraron provisionalmente con un ionómero de vidrio fotopolimerizable. Todos los dientes fueron finalmente restaurados usando restauración directa de resina compuesta y fueron seguidos durante hasta 18 meses, controlando el dolor, el edema y la fístula durante la evaluación clínica. Se realizaron exámenes radiográficos para evaluar la reparación apical hasta los 15 meses, donde se observó el cierre del ápice radicular y la reducción del conducto. Después de 6 meses, se observó evidencia de curación en todos los casos. Se pudo confirmar que la regeneración endodóntica después de la preparación mecanizada del conducto radicular, el uso de un sellador MTA y la restauración directa de resina compuesta en los molares es una opción prometedora para el mantenimiento de los molares permanentes en adolescentes.

Palabras clave: Adolescente; Regeneración; Diente molar; Pulpa dental.

\section{Introduction}

Revascularization is a modality of regenerative endodontic therapy that enables the root canal filling by a new connective tissue, induces the formation of mineralized tissue, providing apical root closure (apexification), and could also induce root growth (maturogenesis) (Saoud et al., 2014, Antunes et al., 2015). The procedure often begins with chemical disinfection using sodium hypochlorite $(\mathrm{NaOCl})$, root canal preparation, and use of intracanal medication to reduce the number of microorganisms in the root canal system (Galler et al., 2016). At a second appointment, bleeding is induced within the canal, promoting the formation of a blood clot by means of stem cells of the apical papilla can migrate (Diogenes et al., 2017). Studies have demonstrated the success of revascularization in permanent necrotic incisors (Wigler et al., 2013, Saoud et al., 2014, Antunes et al., 2015).

Initially, revascularization was indicated only for teeth with incomplete root development (Saoud et al., 2014, Duggal et al., 2017). However, studies have demonstrated the efficiency of this technique in mature permanent teeth (Paryani et al., 2013, Saoud et al., 2016). There are some reports in the literature regarding the treatment of immature permanent molars with regenerative therapy (Martin et al., 2013, Ajram et al., 2019). Nonetheless, the small adherence of this treatment modality to molars is probably related to the anatomical difficulties of disinfection and filling the canal with an adequate volume of blood. Considering that the early loss of molars in young patients affects occlusion, maxillary bone growth and chewing performance, every effort should be made to maintain these teeth (Rodrigues et al., 2020). Therefore, the aim of this study was to report the follow-up of a series of clinical cases of revascularization in severely compromised young permanent molars in adolescents, performed using mechanized root canal preparation.

\section{Methodology}

The present descriptive study consists in a case report series developed from the collaboration between Federal University of Uberlândia team and Dental School of Araraquara located in two different states of Brazil. The study was submitted and approved by the research ethics committee, under protocol 3397587/20. The participants in this study agreed to the Free and 
Informed Consent Term, respecting the Declaration of Helsinki ethical principles.

\section{Case Reports}

Five young patients (9-16 years old) with molar teeth presenting extensive coronary destruction due to caries were selected for this case series study. The patients were referred to the Hebiatric Clinic of the Federal University of Uberlândia, Uberlândia, Brazil, which performs endodontic and restorative treatments in molars of patients aged 6 to 18 years. All teeth had been submitted to emergency treatment for pain relief in the emergency service of the university and had already been submitted to coronary opening.

\section{Anamnesis and clinical examination}

The patient's complaints and medical and dental histories were recorded on the anamnesis form. Extraoral and intraoral examinations were conducted, recording the swelling, presence of sinus tract, vertical percussion, and palpation sensitivity. Preoperative digital periapical radiographs were taken (FIT T2 Microimage, Indaiatuba, SP, Brazil). Based on these data and previous history of pain, a pulpal-periapical diagnosis was determined. The data collected from patients was used to generate the diagnostic hypothesis and are summarized in Table 1.

Table 1. Clinical and radiographic findings: outcomes.

\begin{tabular}{ccccccccc}
\hline $\begin{array}{c}\text { Patient } \\
\mathbf{n}^{\circ}\end{array}$ & Sex & Age & $\begin{array}{c}\text { Tooth } \\
\mathbf{n}^{\circ}\end{array}$ & $\begin{array}{c}\text { Clinical } \\
\text { diagnosis }\end{array}$ & $\begin{array}{c}\text { Time final } \\
\text { restoration }\end{array}$ & $\begin{array}{c}\text { Last } \\
\text { Control } \\
\text { (month) }\end{array}$ & $\begin{array}{c}\text { Periapical status } \\
\text { after endodontic } \\
\text { regenerative } \\
\text { treatment }\end{array}$ & $\begin{array}{c}\text { Root } \\
\text { canal }\end{array}$ \\
\hline 1 & M & 16 & 3 & $\begin{array}{c}\text { Irreversible } \\
\text { pulpite }\end{array}$ & $\begin{array}{c}\text { After } 2 \\
\text { weeks }\end{array}$ & 15 & healed & reduced \\
2 & F & 15 & 31 & $\begin{array}{c}\text { Pulp } \\
\text { necrosis }\end{array}$ & $\begin{array}{c}\text { After } 1 \\
\text { month }\end{array}$ & 15 & healed & reduced \\
3 & M & 14 & 18 & $\begin{array}{c}\text { Pulp } \\
\text { necrosis }\end{array}$ & $\begin{array}{c}\text { After } 6 \\
\text { months }\end{array}$ & 15 & healed & reduced \\
4 & F & 13 & 31 & $\begin{array}{c}\text { Irreversible } \\
\text { pulpite }\end{array}$ & $\begin{array}{c}\text { After } 4 \\
\text { months }\end{array}$ & 15 & healing & normal \\
5 & M & 9 & 30 & $\begin{array}{c}\text { Irreversible } \\
\text { pulpite }\end{array}$ & After 1 week & 15 & healed & reduced \\
\hline
\end{tabular}

F, female; M, male. Source: Authors.

Of the five teeth treated, one was mandibular first molar, three were mandibular second molars and one was mandibular first molar; only one tooth had all the root canals with large open apexes. The one maxillary molar treated had complete root development, showing slightly open foramina in the palatal root canal.

\section{Summary of procedures}

\section{First Visit}

In the first session, the following procedures were conducted: local anesthesia with $2 \%$ lidocaine containing 1: 100000 epinephrine (DFL, Rio de Janeiro, RJ, Brazil), rubber dam isolation, and removal of temporary restorative material. After root 
canal access performed using rounded carbide burs and Endo Z bur (Malleifer, Dentsply, Petrópolis, RJ, Brazil, they were irrigated with approximately $10 \mathrm{ml}$ of $2.5 \%$ sodium hypochlorite (Asfer, São Caetano do Sul, SP, Brazil) delivered by a $27-$ gauge open-ended and explored with \#10-15 hand K-files (Dentsply Maillefer, Oklahoma, USA). To avoid the stress caused by rotatory files during the root canal preparations, the coronal third of root canal was prepared with \#15-25 H-files (Dentsply Maillefer, Oklahoma, USA) and Gates Glidden drill sizes \#2 and \#3 (Dentsply Maillefer, Oklahoma, USA). A working length 1 $\mathrm{mm}$ short of the radiographic apex was determined using periapical radiographs. Then, root canals were prepared with Protaper Next rotary files (Dentsply) X1-X4 under copious irrigation using $\mathrm{NaOCl}$. The final irrigation was performed with $10 \mathrm{ml}$ of saline solution (Equiplex, Aparecida de Goiania, Brazil). Root canals were dried with sterile paper points and dressed with calcium hydroxide paste (Ultracal, Ultradent, Southern Jordan, UT, USA). The pulp chamber was sealed with a sterile cotton pellet and filled using conventional glass ionomer cement (Maxxion R, FGM, Joinville, SC, Brazil).

\section{Second Visit}

At least two weeks after the first treatment visit, the asymptomatic teeth were submitted to the revascularization procedure. The procedure was performed with local infiltrative anesthesia of $2 \%$ lidocaine (DFL, Brazil) without vasoconstrictor followed by rubber dam isolation and removal of provisional restoration. Calcium hydroxide paste was removed from the root canals using K-files and $20 \mathrm{ml}$ irrigation of $2.5 \% \mathrm{NaOCl}$, followed by $10 \mathrm{ml}$ of sterile saline solution and drying with sterile paper points. Then, the root canal was irrigated with $3 \mathrm{ml}$ of $17 \%$ EDTA $(1 \mathrm{ml} / \mathrm{min})$ under ultrasonic stirring (E1-Irrisonic, Helse, Santa Rosa de Viterbo, Sao Paulo, Brazil) and dried with paper points (Dentsply). Apical bleeding was induced by passing with K-file size \#15 (for mandibular mesial or maxillary buccal canals) or \#20-25 (for mandibular distal or maxillary palatal canals) approximately $2 \mathrm{~mm}$ beyond the apex. The filling of root canals by the clots was accompanied by $3 \mathrm{x}$ magnification using a surgical microscope (DFV, Valença, RJ, Brazil). After approximately 10 minutes, when the blood became semi coagulated, MTA (Angelus, Londrina, PR, Brazil) was mixed and introduced into the coronal part of each canal using an appropriate device similar to a miniature amalgam carrier (MTA Applicator, Angelus, Londrina, PR, Brazil) and was vertically condensed. The collagen matrix was not used because the space inside the root canal was insufficient. The pulp chamber was filled with resinmodified glass ionomer cement (Riva, SDI, São Paulo, SP, Brazil). A postoperative radiograph was taken using FIT T2.

\section{Third Visit}

The final coronal restoration was performed by removing partially the resin-modified glass ionomer, and the coronal portion was filled using bulk fill composite resin. Selective enamel etching was performed using 37\% phosphoric acid (Condac 37, FGM) for 30 seconds, followed by washing using air/dry spray for 30 seconds and gentle drying using absorbent paper. The self-etching adhesive system (Ambar APS, FGM) was actively applied using a microbrush (Cavibrush, FGM), followed by gently air spray for solvent evaporation. The adhesive system was light cured for 10 seconds using a light curing unit with 1400 $\mathrm{mW} / \mathrm{cm}^{2}$ (VALO Cordless, Ultradent). The depth of cavity was checked using a periodontal probe (Hu-Friedy, Chicago, IL, USA), and the regular paste composite resin (Opus bulk fill APS, FGM, Joinville, SC, Brazil) was inserted into an increment of $5 \mathrm{~mm}$ in thickness and was light cured in each occlusal/mesial and occlusal/distal region for 40 seconds. The second increment was inserted, and the occlusal anatomy was defined using a sculpting spatula (Millenium, Golgran, São Caetano do Sul, SP, Brazil). All procedures were performed under rubber dam isolation. The time between the conclusion of endodontic treatment and definitive restoration with bulk fill composite resin ranged from 7 days to 6 months; however, during this period, glass ionomer cement provisional restoration was maintained and checked periodically. 


\section{Results}

In the present study, the follow-up of the treatments was performed based on the parameters described by Orstavik $e t$ al. (1986) and Saoud et al. (2016), which classified the outcome as healed, healing, and disease. Some modifications to the original criteria were added: healed was defined as a tooth without clinical signs and symptoms and periapical radiography with normal appearance; healing was defined as a tooth with reduction of the periapical lesion, without clinical signs and symptoms; and diseased was defined as development or persistence of periapical lesion associated or not with the presence of clinical signs and symptoms. In addition, apical closure or reduction of canal lumen by deposition of mineralized tissue was verified. The clinical and radiographic data obtained from each patient are summarized in Table 1. The follow-up occurred 1 month after the conclusion of the endodontic treatment and afterward every 3 months until 15 months of follow-up.

Clinical case 1 (Figure 1A-1C), of the oldest patients (16 years old), involved treatment performed in the upper molar.

Figure 1 - Case 1.
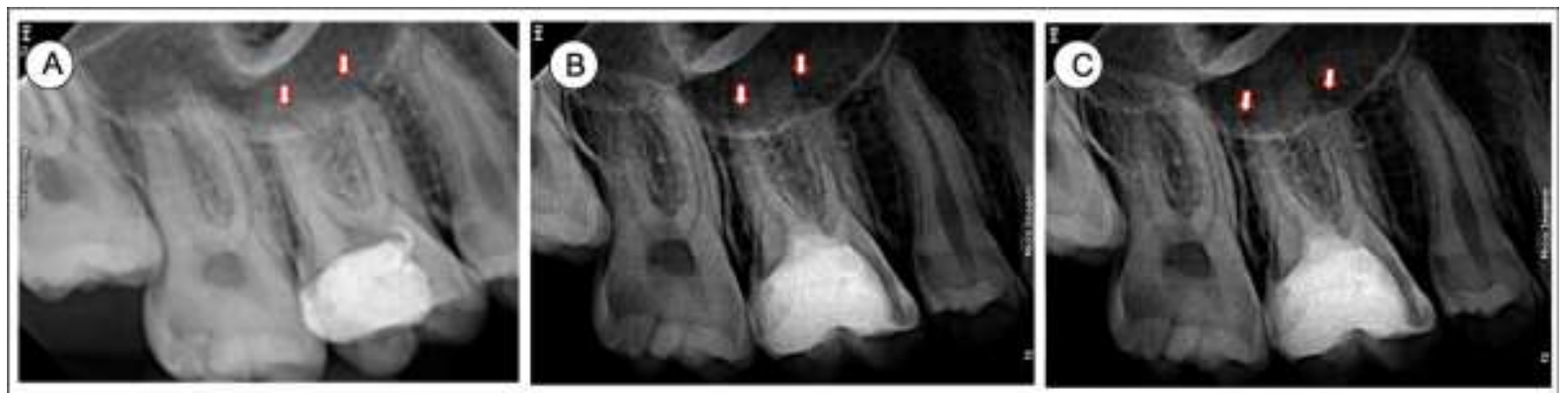

Figure 1 - (A) X-ray image of mandibular first molar showing complete root canal formation and slight thickening of the periodontal ligament (arrows). (B) X-ray image of six-month follow-up showing normal root canal apex appearance (arrow). (C) Final $X$-ray image after fifteenmonth follow-up showing reduction in the canal volume (arrow). Source: Authors.

It is possible to observe that at the initial appointment, only the lingual root canal had a slightly open apex, which was confirmed after endodontic file exploration. The other root canals were not large, and periodontal ligament space was slightly thickened, although no radiographic periapical lesion was present. The tooth was classified as healed at 12 months after endodontic treatment, with a reduction in the space of the periodontal ligament for normal parameters. A slight reduction of the canal lumen was also observed.

Clinical cases 2 (Figure 2A-2C), 3 (Figure 3A-3C), and 4 (Figure 4A-4C) presented open apex only in the distal root as demonstrated in following images. All teeth received the same treatment protocol.

Figure 2 - Case 2.


Figure 2 - (A) X-ray image of mandibular first molar showing larger volume of root canal and open distal canal apex (arrows). (B) X-ray image of six-month follow-up demonstrating normal appearance of both root canal apexes (arrow). (C) Final X-ray image after fifteen-month follow-up showing reduction in the canal volume and the apex closing (arrow). Source: Authors. 
In case 2, fifteen months after the regenerative endodontic therapy, the distal root canal apex was closed and the tooth was classified as healed, reducing the periodontal ligament space to normal parameters (Figure 2C).

Figure 3 - Case 3.


Figure 3 - (A) X-ray image of mandibular second molar showing open distal canal apex (arrows). (B) X-ray image of six-month follow-up demonstrating normal appearance of both root canal apexes (arrow). (C) Final X-ray image after fifteen-month follow-up showing the apex closing (arrow). Source: Authors.

Similar to what was observed in case 2, case 3 presented a reduction in the lumen of the root canals, suggesting possible obliteration (Figure 2A-3C).

Figure 4 - Case 4.

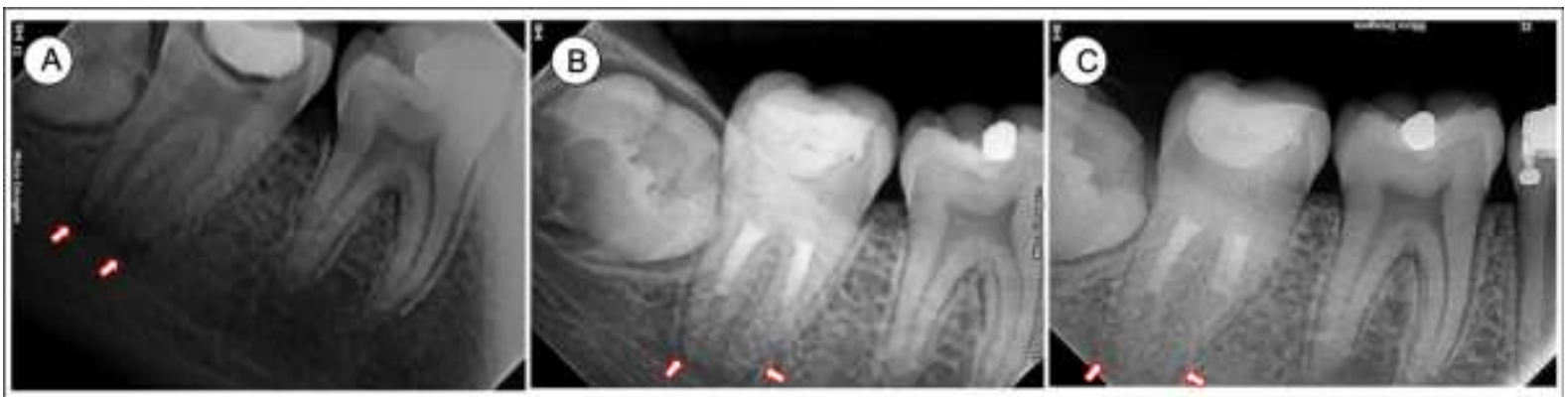

Figure 4 - (A) X-ray image of mandibular first molar showing larger volume of root canal and open distal canal apex (arrows). (B) X-ray image of six-month follow-up demonstrating normal appearance of both root canal apexes (arrow). (C) Final X-ray image after fifteen-month follow-up showing reduction in the canal volume and the apex closing (arrow). Source: Authors.

The clinical case 4 had a large distal canal, but at 6 months after treatment, signs of volume reduction and apical repair were identified, which was confirmed at the end of the follow-up period. Clinical case 5 (Figure 5A-5C) was the youngest patient (9 years old), presenting more voluminous canals compared to the others, thinner dentinal walls and all open apexes.

Figure 5 - Case 5.
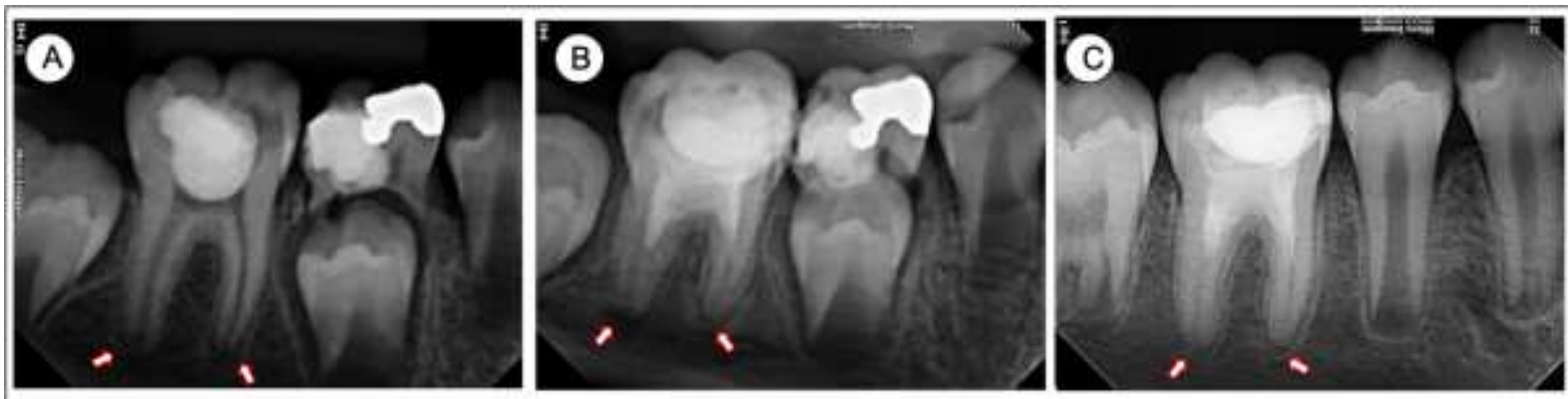

Figure 5 - (A) X-ray image of mandibular first molar showing larger volume of root canal and both open canal apexes (arrows). (B) X-ray image of three-month follow-up demonstrating reduction in canal lumen and normal appearance of both root canal apexes (arrow). (C) Final $X$-ray image after fifteen-month follow-up showing greater reduction in the canal volume and both apexes closing (arrow). Fonte: Autores. 
At the initial appointment, in Case 5, a wide distal canal with open apex, increased periodontal ligament space, and initial signs of apical radiolucent development were verified. After treatment, in follow-up visits, a reduction in canal lumen and apical repair were verified, classifying the tooth as healing up to 6 months.

\section{Discussion}

The published case reports of regenerative endodontic treatments enrolling permanent molars (Ajram et al., 2019, Zhujiang et al., 2016) indicated that there is no standardized clinical protocol established for this treatment (Kontakiotis et al., 2015). Some authors report the procedure in a single appointment (Topçuoğlu et al., 2016), whereas others use two or more appointments (Ajram et al., 2019, Zhujiang et al., 2016, Dhaimy et al., 2017). In the present report, the regenerative endodontic procedures were completed in two appointments, because the coronary openings were done previously at the beginning of the treatment in emergency service. The clinical cases were considered healed after 15 months of evaluation. The literature presents several factors responsible for the success of regenerative endodontic treatments, such as root canal disinfection and apical papilla stem cell survival (SCAP) (Diogenes et al., 2017, Duggal et al., 2017).

Previous studies have shown that SCAPs are responsible for tissue repair (Sonoyama et al., 2006, Huang et al., 2010); thus, their survival directly influences the potential for cell differentiation and repair. SCAPs have high proliferative potential and are able to differentiate into several cell subtypes, such as osteogenic, odontogenic, and neurogenic cells (Sonoyama et al., 2006). SCAPs induce tissue repair by depositing a continuous layer of dentin-like tissue (Huang et al., 2010), promoting additional development in thickness and length (Diogenes et al., 2016, Diogenes et al., 2017). Such condition was observed in clinical case 5 when analyzing the apical third of the distal root. Another factor that may also influence the viability of the SCAPs is the concentration of $\mathrm{NaOCl}$ used (Martin et al., 2020, Antunes et al., 2015). Although this is the most used irrigating solution in regenerative endodontic treatments, the recommended concentration to be used is variable (Antunes et al., 2015, Kontakiotis et al., 2015). In the present study, $2.5 \% \mathrm{NaOCl}$ was chosen, which is a potent antimicrobial agent capable of dissolving organic matter (Yang et al., 1995). In vitro studies demonstrated that $2.5 \% \mathrm{NaOCl}$ solutions do not compromise the survival of SCAPs, although higher concentrations are not recommended due to their cytotoxicity (Trevino et al 2011, Galler et al., 2011). The use of 17\% EDTA as final irrigation in cases of revascularization is also recommended (Galler et al., 2011, Kontakiotis et al., 2015). Its use is supported by chelating capability that promotes the release of growth factors trapped in dentine, favoring the adhesion of SCAPs in dentine walls, without interfering with their survival (Trevino et al., 2011).

The use of intracanal medication in teeth undergoing revascularization is indicated, in most randomized clinical trials and case series reports, the procedure is performed in at least two appointments (Ajram et al., 2019, Dhaimy et al., 2017, Zhujiang et al., 2016). However, there is no consensus about the intracanal medication to be used in regenerative endodontic procedures. While some authors prefer triantibiotic paste (TAP) (Song et al., 2017), others prefer calcium hydroxide $\left(\mathrm{Ca}(\mathrm{OH})_{2}\right)(\mathrm{Ruparel}$ et al., 2012, Althumairy et al., 2014). Based on previous studies that showed that $\mathrm{Ca}(\mathrm{OH})_{2}$ paste is less cytotoxic than TAP to cells in periapical tissues (Ruparel et al., 2012, Althumairy et al., 2014)., Ultracal ${ }^{\circledR}$, a ready-to-use $\mathrm{Ca}(\mathrm{OH})_{2}$ paste, was used. In addition, $\mathrm{Ca}(\mathrm{OH})_{2}$ paste is easier to remove than TAP paste (Berkhoff et al., 2014). However, it has been suggested that root canal obliterations are more related to the use of $\mathrm{Ca}(\mathrm{OH})_{2}$ (Song et al., 2017). It was possible to observe that clinical cases 1,2 , 3 , and 5 showed a significant reduction in canal volume in the first 12 months, which could be inferred to be related to this statement.

Another important factor for the success of regenerative endodontic treatment is the promotion of the clot, which is induced by the bleeding technique (Duggal et al., 2017). To confirm that there was adequate canal filling by the clot, all cases were treated using a $3 x$ magnification microscope. Molars have canals with a smaller diameter and greater anatomical complexity than incisors, which are usually submitted to regenerative procedures. This fact makes it difficult to induce clotting (Dhaimy $e t$ 
al., 2017), as observed by the operators in this series of cases. Proper coronal sealing to seal the clot and prevent bacterial contamination is another key factor for successful revascularization (Lin et al., 2014). The MTA was used to seal the canals because it has good sealing properties and excellent biocompatibility (Lin et al., 2014). This was followed by the insertion of resin-modified glass ionomer cement. However, in four teeth, definitive bulk fill composite resin restorations took a long time to perform. This situation is probably related to the fact that RIVA provides proper aesthetics, masticatory efficiency, and sealing capacity, which resulted in the relatives of the adolescents missing consultations. Regarding the biomechanical preparation of root canals, the American Association of Endodontists do not recommend mechanized instrumentation of the root canals (American Association of Endodontics, 2020), although mild instrumentation is generally used (Kontakiotis et al., 2015, Dhaimy et al., 2017). In present report the protocol was modified to in order to meet the specificities observed in young molars.

This is the first series of cases to describe an instrumentation sequence to be used on young molars whose root canals are not as wide and whose apexes are not all opened. The preparation of the cervical third using Hedstroem files and Gates Glidden drills, followed by preparation by Protaper Next files, was used to achieve effective biomechanical preparation, reducing the contamination. To facilitate the root canal shaping, the mesial canals of the mandibular molars were enlarged, subsequently allowing more effective induction of the clot. This technical modification did not affect the prognosis of the treatments. Even in the adverse conditions found, characterized by teeth largely destroyed by caries and previously exposed to the oral environment, success was obtained, which were considered healed/healing. Moreover, in clinical cases 2, 3, 4, and 5, the apex closure of the distal roots occurred. The lack of response to the pulp sensitivity test during follow-up appointments does not necessarily mean that the tooth has no vitality (Law AS, 2013) because the thickness of sealing material present on the tooth may affect the response to the cold sensitivity test (Torabinejad et al., 2011). All the procedures performed in this series of clinical cases were able to maintain the young permanent molars, contributing to stability of the growing process, masticatory performance, and occlusal stability.

\section{Conclusion}

It is possible to perform regenerative endodontic procedures in young molars severely compromised by caries and obtain success. The instrumentation sequence proposed in this series of clinical cases, which combines hand files, Gates Glidden drills, and a modified Protaper Next technique, did not negatively affect treatment prognosis. Therefore, it is possible to perform this treatment sequence as a method of mechanical disinfection of root canals prior to clot induction in young molars. Another important aspect is that the direct composite resin restoration must be performed as soon as possible after the clot induction. Clinical studies should be performed on young permanent molars undergoing revascularization to assess the longevity of this treatment compared to conventional endodontic treatment.

\section{Acknowledgements}

The authors are grateful with CAPES finance code 001, FAPEMIG and CNPq for financial support of this clinical service.

\section{References}

Ajram, J., Khalil, I., Gergi, R., \& Zogheib, C. (2019) Management of an Immature Necrotic Permanent Molar with Apical Periodontitis Treated by Regenerative Endodontic Protocol Using Calcium Hydroxide and MM-MTA: A Case Report with Two Years Follow Up. Dent J (Basel), 7:1.

Althumairy, R. I., Teixeira, F. B., \& Diogenes, A. (2014) Effect of dentin conditioning with intracanal medicaments on survival of stem cells of apical papilla. J. Endod, 40: 521-5. 
research/research/regenerative-database/

Antunes, L. S., Salles, A. G., Gomes, C.C., Andrade, T. B., Delmindo, M. P., \& Antunes, L. A. A. (2015). The effectiveness of pulp revascularization in root formation of necrotic immature permanent teeth: A systematic review. Acta Odontologica Scandinavica, 74:161-9.

Berkhoff, J. A., Chen, P. B., Teixeira, F. B., \& Diogenes, A. (2014). Evaluation of triple antibiotic paste removal by different irrigation procedures. J Endod, 40:1172-7.

Dhaimy, S., Dhoum, S., Amarir, H., El Merini, H., Nadifi, S., \& Ouazzani, A. E. (2017). Pulpo-Periodontal Regeneration: Management of Partial Failure Revascularization. Case Rep Dent, 2017:8302039.

Diogenes, A., Ruparel, N. B., Shiloah, Y., \& Hargreaves, K. M. (2016). Regenerative endodontics: A way forward. J Am Dent Assoc, 147:372-80.

Diogenes, A. \& Ruparel, N. B. (2017). Regenerative Endodontic Procedures: Clinical Outcomes. Dent Clin North Am, 61:111-5. 1.

Duggal, M., Tong, H. J., Al-Ansary, M., Twati, W., Day, P. F. \& Nazzal, H. (2017) Interventions for the endodontic management of non-vital traumatised immature permanent anterior teeth in children and adolescents: a systematic review of the evidence and guidelines of the European Academy of Paediatric Dentistry. Eur Arch Paediatr Dent, 18:139-151.

Galler, K. M. (2016). Clinical procedures for revitalization: current knowledge and considerations. Int Endod J. 49(10):926-36.

Galler, K. M., D’Souza, R. N., Federlin, M., Cavender, A. C., Hartgerink, J. D., Hecker, S. \& Schmalz, G. (2011). Dentin conditioning codetermines cell fate in regenerative endodontics. $J$ Endod, 37:1536-41.

Huang, G. T., Yamaza, T., Shea, L. D., Djouad, F., Kuhn, N. Z., Tuan, R. S. \& Shi, S. (2010). Stem/progenitor cell-mediated de novo regeneration of dental pulp with newly deposited continuous layer of dentin in an in vivo model. Tissue Eng, 6:605-15.

Kontakiotis, E. G., Filippatos, C. G., Tzanetakis, G. N. \& Agrafioti, A. (2015). Regenerative endodontic therapy: a data analysis of clinical protocols. J Endod, 41:146-54.

Law, A. S. Considerations for regeneration procedures. (2013). J Endod, 39:44-56.

Lin, L. M., Shimizu, E., Gibbs, J. L., Loghin, S. \& Ricucci, D. (2014). Histologic and histobacteriologic observations of failed revascularization/revitalization therapy: A case report. J Endod, 40:291-25.

Martin, D. E., De Almeida, J. F., Henry, M. A., Khaing, Z. Z., Schmidt, C. E., Teixeira, F. B. \& Diogenes, A. (2014). Concentration-dependent effect of sodium hypochlorite on stem cells of apical papilla survival and differentiation. J Endod, 40:51-5.

Martin, G., Ricucci, D., Gibbs, J. L. \& Lin, L. M. (2013). Histological findings of revascularized/revitalized immature permanent molar with apical periodontitis using platelet-rich plasma. J Endod, 39:138-44.

Orstavik, D., Kerekes, K. \& Eriksen, H. M. (1986). The periapical index: a scoring system for radiographic assessment of apical periodontitis. Endodontics \& Dental Traumatology, 2:20-3.

Paryani, K. \& Kim, S. G. (2013). Regenerative endodontic treatment of permanent teeth after completion of root development: a report of 2 cases. $J$ Endod, 39:929-34.

Rodrigues, M. P., Soares, P. B. F., Gomes, M. A. B., Pereira, R. A., Tantbirojn D., Versluis A. \& Soares C. J. (2020). Direct resin composite restoration of endodontically-treated permanente molars in adolescents: bite force and patient-specific finite element analysis. J Applied Oral Scienc.

Ruparel, N. B., Teixeira, F. B., Ferraz, C.C. \& Diogenes, A. (2012). Direct effect of intracanal medicaments on survival of stem cells of the apical papilla. $J$ Endod, 38:1372-5.

Saoud, T. M., Martin,G., Chen, Y. H., Chen, K. L., Chen, C. A., Songtrakul, K., Malek, M., Sigurdsson, A. \& Lin L. M. (2016). Treatment of Mature Permanent Teeth with Necrotic Pulps and Apical Periodontitis Using Regenerative Endodontic Procedures: A Case Series. J Endod, 42:57-65.

Saoud, T. M., Zaazou, A., Nabil, A., Moussa, S., Lin, L. M. \& Gibbs, J. L. (2014). Clinical and radiographic outcomes of traumatized immature permanent necrotic teeth after revascularization/revitalization therapy. J Endod, 40:1946-52.

Song, M., Cao, Y., Shin, S. J., Shon, W. J., Chugal, N., Kim, R. H., Kim, E. \& Kang, M. K. (2017). Revascularization-associated Intracanal Calcification: Assessment of Prevalence and Contributing Factors. J Endod, 43:2025-33.

Sonoyama, W., Liu, Y., Fang, D., Yamaza, T., Seo, B. M., Zhang, C., Liu, H., Gronthos, S., Wang, C. Y., Wang, S. \& Shi, S. (2006). Mesenchymal stem cellmediated functional tooth regeneration in swine. PLoS One, 20;1:e79.

Topçuoğlu, G. \& Topçuoğlu, H. S. (2016). Regenerative Endodontic Therapy in a Single Visit Using Platelet-rich Plasma and Biodentine in Necrotic and Asymptomatic Immature Molar Teeth: A Report of 3 Cases. J Endod, 42:1344-6.

Torabinejad, M. \& Turman, M. (2011). Revitalization of tooth with necrotic pulp and open apex by using platelet-rich plasma: a case report. $J$ Endod, 37:2658 .

Trevino, E. G., Patwardhan, A. N., Henry, M. A., Perry, G., Dybdal-Hargreaves, N., Hargreaves, K. M. \& Diogenes, A. (2011). Effect of irrigants on the survival of human stem cells of the apical papilla in a platelet-rich plasma scaffold in human root tips. $J$ Endod, 37:1109-15.

Zhujiang, A. \& Kim, S. G. (2016). Regenerative Endodontic Treatment of an Immature Necrotic Molar with Arrested Root Development by Using Recombinant Human Platelet-derived Growth Factor: A Case Report. J Endod, 42:72-5. 
Research, Society and Development, v. 10, n. 5, e20810514532, 2021

(CC BY 4.0) | ISSN 2525-3409 | DOI: http://dx.doi.org/10.33448/rsd-v10i5.14532

Wigler, R., Kaufman, A. Y., Lin, S., Steinbock, N., Hazan-Molina, H. \& Torneck, C. D. (2013). Revascularization: a treatment for permanent teeth with necrotic pulp and incomplete root development. J Endod, 39:319-26.

Yang, S. F., Rivera, E. M., Baumgardner, K. R., Walton, R. E. \& Stanford, C. (1995). Anaerobic tissue-dissolving abilities of calcium hydroxide and sodium hypochlorite. J Endod, 21:613-6. 